\title{
Distinct patterns in the size-scaling of abundance and metabolism in coastal and open-ocean phytoplankton communities
}

\author{
M. Huete-Ortega ${ }^{1,5, *}$, T. Rodríguez-Ramos ${ }^{2}$, D. C. López-Sandoval ${ }^{2,3}$, P. Cermeño $^{3}$, \\ J. M. Blanco ${ }^{4}$, R. L. Palomino ${ }^{4}$, J. Rodríguez ${ }^{4}$, E. Marañón ${ }^{2}$ \\ ${ }^{1}$ School of Biological Sciences, University of Essex, Colchester CO4 3SQ, UK \\ ${ }^{2}$ Departamento de Ecoloxía y Bioloxía Animal, Universidade de Vigo, 36210 Vigo, Spain \\ ${ }^{3}$ Instituto de Ciencias del Mar, Passeig Maritim de la Barceloneta 37-49, 08003 Barcelona, Spain \\ ${ }^{4}$ Departamento de Ecología y Geología, Universidad de Málaga, 29071 Málaga, Spain
}

${ }^{5}$ Present address: Department of Chemical and Biological Engineering, The University of Sheffield, Sheffield S1 3DJ, UK

\begin{abstract}
This study was aimed at identifying macroecological patterns in the relationship between phytoplankton cell size, abundance and metabolism in 2 marine ecosystems characterised by marked differences in resource availability and water-column stability. Several patterns emerged: (1) nearly isometric size-scaling of phytoplankton carbon fixation rate was described for both open-ocean and coastal ecosystems (mean slope: 1.17 and 0.90, respectively), supporting the idea that biomass-specific photosynthesis rates are largely independent of cell size; (2) less steep values for the size-scaling of abundance (mean slope: -0.73) were found in the coastal ecosystem compared to the open ocean (mean slope: -1.15); (3) large phytoplankton used more photosynthetic energy than smaller cells in the coastal ecosystem, but a constant flow of energy along the size spectrum was found in the open ocean; and (4) phytoplankton biomass turnover rates were 1 order of magnitude higher in the coastal ecosystem than in the open ocean, implying physiological limitation of phytoplankton growth in the oligotrophic ocean. Bottom-up and top-down mechanisms and their interaction with nutrient supply dynamics were suggested as major factors determining the contrasting phytoplankton size abundance distributions observed in coastal and openocean waters.
\end{abstract}

KEY WORDS: Phytoplankton $\cdot$ Cell size $\cdot$ Metabolism $\cdot$ Size-scaling $\cdot$ Abundance $\cdot$ Growth rate Resale or republication not permitted without written consent of the publisher

\section{INTRODUCTION}

Phytoplankton account for nearly half of the global primary production (Field et al. 1998), helping to regulate atmospheric carbon dioxide levels, and thus Earth's climate, on decadal to millennial time-scales (Falkowski et al. 1998). It is therefore important to better understand patterns in the phytoplankton community structure and metabolism, and how the environmental forces shape them. Trait-based approaches have recently gained increasing attention in ecology, and specifically in marine ecology, because they are a useful tool to explain the organization of ecological communities (McGill et al. 2006, Westoby \& Wright 2006, Litchman et al. 2012). Phytoplankton cell size, which spans $>9$ orders of magnitude in cell volume, is considered to be a master trait both at the organismal and ecological organization levels, with a great potential for explaining phytoplankton community structure and functioning. On the one hand, individual 
phytoplankton cell size influences growth, metabolic rates, access to and assimilation of resources, sedimentation rates, and susceptibility to grazing (Kiørboe 1993, Litchman \& Klausmeier 2008). On the other hand, the size abundance distribution of phytoplankton communities play a fundamental role in marine pelagic ecosystems, influencing the trophic organization of plankton communities and the biogeochemical cycling of many elements, including carbon, nitrogen, and phosphorous (Kiørboe 1993, Legendre \& Rassoulzadegan 1996, Falkowski et al. 2004).

Metabolic rates such as carbon fixation, respiration, or nutrient and light acquisition are related to body size by a power function of the form $M=c V^{d}$, where $M$ is a metabolic rate, $c$ is a coefficient, which can be taxon-specific, $V$ is organism size (biovolume), and $d$ is the size-scaling exponent, which commonly takes a value of approximately 0.75 (Kleiber's law; Kleiber 1947, Peters 1983). Using logarithms, the power function yields the linear relationship $\log M=$ $\log c+d \log V$, where $d$ is the slope value. Although previous studies have been in agreement with the applicability of Kleiber's law to marine and freshwater protists (Taguchi 1976, López-Urrutia et al. 2006), recent reports have shown that carbon fixation, carbon exudation, and respiration rates in prokaryotic and eukaryotic phytoplankton scales to cell size with an exponent close to 1 , both in laboratory and field experiments (Marañón et al. 2007, 2013, Johnson et al. 2009, Huete-Ortega et al. 2012, LópezSandoval et al. 2013, 2014). Mass-specific metabolic rates are therefore largely independent of cell size, meaning that large phytoplankton can sustain similar metabolic rates to those of smaller cells.

The relationship between phytoplankton abundance and cell size has been widely studied in aquatic ecosystems since the seminal work of Sheldon et al. (1972). Similar to the scaling of metabolism, the number of individuals follows a power function such that $N=a V^{b}$, where $N$ is cell abundance and $\log a$ is the intercept of the resulting linear regression. The sizescaling exponent, $b$, is a synthetic descriptor of community size structure, and generally takes values between -1.3 and -0.6 depending on the productivity of the ecosystem (Marquet et al. 2005). For instance, steeper slopes (-1.3 to -1.1$)$ have been reported for unproductive ecosystems typical of subtropical regions (Cavender-Bares et al. 2001, Cermeño \& Figueiras 2008), whereas the slopes become less negative $(-0.8$ to -0.6 ) in productive coastal ecosystems, reflecting the increased relative abundance of large phytoplankton (Reul et al. 2005, Marañón et al. 2007, HueteOrtega et al. 2010).
Previous studies have attempted to elucidate the underlying mechanisms explaining the regularity and persistence of phytoplankton size abundance distributions across broad temporal and spatial scales, using field-, laboratory- and modeling-based approaches (e.g. Irwin et al. 2006, Finkel et al. 2009, Edwards et al. 2011, Ward et al. 2012). It has been also noted that multiple processes such as the sizedependence of grazing pressure or nutrient uptake rate can give rise to similar size-scaling relationships (Poulin \& Franks 2010). In this study, we explore the idea that the relevant underlying processes can also vary among ecosystems, implying that no single mechanism explains size-scaling relationships in all environments. In the oligotrophic Atlantic Ocean, the size-scaling of phytoplankton abundance has been linked to the size-scaling of cell-specific carbon fixation rate, which can be used as a proxy of individual resource use (Huete-Ortega et al. 2012). Here, we extend that work by concurrently analyzing the sizescaling of carbon fixation rate per cell and total phytoplankton abundance in a highly dynamic and productive coastal ecosystem from the NW Iberian Peninsula. Our main objective is to identify and explain macroecological patterns in the relationship between cell size, abundance, biomass, and metabolism of phytoplankton communities by comparing coastal and open-ocean ecosystems.

\section{MATERIALS AND METHODS}

\section{Study sites, sampling, and hydrography}

Two contrasting marine ecosystems were chosen for this study: the subtropical and tropical Atlantic Ocean, as representative of an oligotrophic, close to steady-state ecosystem, and the coastal waters of Ría de Vigo in the NW Iberian Peninsula, representative of a highly productive, dynamic ecosystem that is strongly influenced by upwelling events (Fig. 1). The subtropical and tropical Atlantic Ocean, hereafter referred as the open-ocean ecosystem, was sampled during a cruise carried out in November to December 2007 on board the R/V 'Hespérides'. Details of the sampling and hydrography characterization of the 17 visited stations are given by Huete-Ortega et al. (2011).

In the NW Iberian Peninsula, henceforth referred to as the coastal ecosystem, 2 stations located inside and outside (shelf) Ría de Vigo $\left(42.24^{\circ} \mathrm{N}, 8.79^{\circ} \mathrm{W}\right.$ and $42.16^{\circ} \mathrm{N}, 8.94^{\circ} \mathrm{W}$, respectively) were visited twice a month from May to July 2010 on board the R/V 


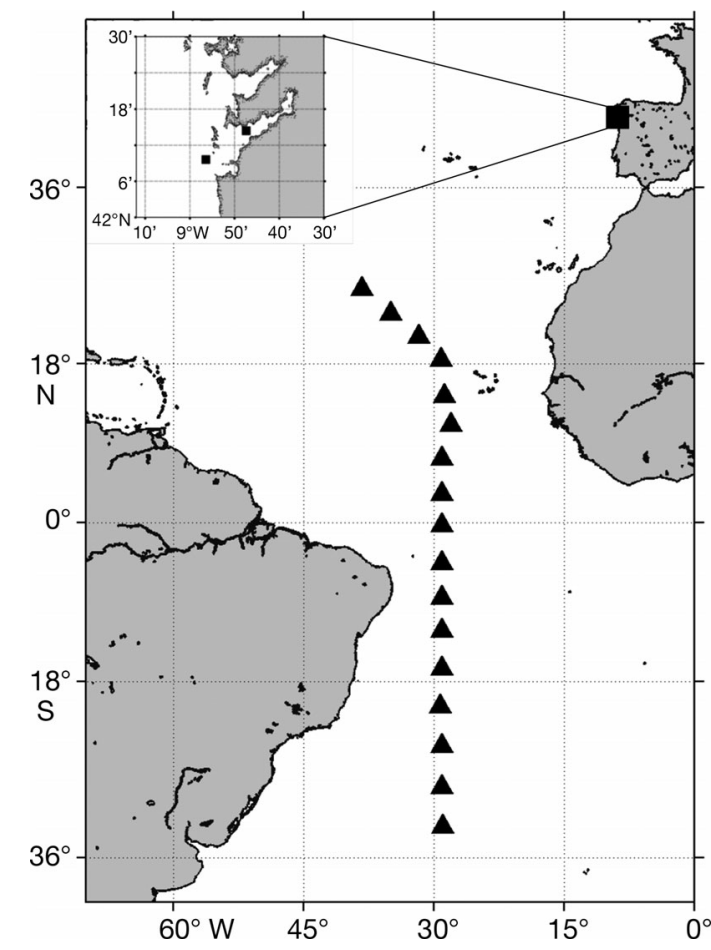

Fig. 1. Location of sampling sites. Triangles refer to the sampling stations of the subtropical and tropical Atlantic Ocean. Squares point to the location of the 2 sampling stations of the NW Iberian Peninsula, inside and outside of Ría de Vigo

'Mytilus'. At each sampling site, vertical profiles (0-40 and $0-78 \mathrm{~m}$, respectively) of temperature, salinity and in situ fluorescence were obtained using a CTD SBE 25 probe attached to a rosette sampler equipped with Niskin bottles. Using the density calculated from the temperature and salinity data, we estimated the Brunt-Väisäla frequency $(N)$ averaged over the euphotic layer depth, as a proxy of water column stability, following the equation detailed by HueteOrtega et al. (2011).

\section{Size-fractionated carbon fixation rate}

Photosynthetic carbon fixation rates were measured with the ${ }^{14} \mathrm{C}$-uptake technique in both regions, although with some methodological differences regarding the volume and incubation of the samples. In the case of the open-ocean ecosystem, the sampling and incubation methodology was as detailed by Huete-Ortega et al. (2011). Similar methodology was followed in the coastal ecosystem, although in this region, surface $(5 \mathrm{~m})$ samples were collected in $250 \mathrm{ml}$ bottles, inoculated with $\sim 50 \mathrm{~Bq} \mathrm{NaH}_{14} \mathrm{CO}_{3}$, and incubated in the laboratory for $4 \mathrm{~h}$. Incubation took place in an indoor incubation chamber with irra- diance and temperature simulating the in situ conditions encountered each sampling day (40 to $500 \mu \mathrm{E}$ $\mathrm{m}^{-2} \mathrm{~s}^{-1}$ and $15^{\circ} \mathrm{C}$ on average). At the end of the incubation, water samples were processed as detailed by Huete-Ortega et al. (2011), although in the coastal ecosystem, the whole $250 \mathrm{ml}$ were filtered through all the filters. In both cases, the amount of organic ${ }^{14} \mathrm{C}$ present in the filters and carbon fixation rates by each size class $(0.2-0.8,0.8-2,2-3,3-5,5-10,10-20$, $20-41$, and $>41 \mu \mathrm{m}$ in equivalent spherical diameter [ESD]) were calculated as described by Marañón et al. (2001).

\section{Size-fractionated chlorophyll a}

Size-fractionated chlorophyll a (chl a) concentration in both regions was determined as detailed by Huete-Ortega et al. (2011) in the same size classes indicated above for the carbon fixation rate, with the particularity that for the coastal ecosystem, 2 replicates of $250 \mathrm{ml}$ surface seawater were sequentially filtered through all the filters. Total chl a values were calculated as the sum of all size-fractionated chl $a$ concentrations.

\section{Phytoplankton cell size and abundance}

The abundance of surface pico- $(<2 \mu \mathrm{m}$ ESD) and small nano-phytoplankton (2 to $5 \mu \mathrm{m}$ ESD) was determined by flow cytometry using a FACSCalibur flow cytometer (Becton Dickinson) as described by Reul et al. (2005) and Huete-Ortega et al. (2011). Large nano(5 to $20 \mu \mathrm{m}$ ESD) and micro- ( $>20 \mu \mathrm{m}$ ESD) phytoplankton were determined by image analysis under an inverted microscope following the method of Utermöhl (Lund et al. 1958). The methodology used for the samples taken in the open-ocean ecosystem is detailed by Huete-Ortega et al. (2011). In the coastal system, similar procedures were followed for the $500 \mathrm{ml}$ and 11 surface seawater samples taken from inside and outside Ría de Vigo, respectively, by using an inverted microscope Leica DMLB connected to a Pike F145C camera. In the case of chain-forming organisms (Rhizosolenia spp., Pseudonitzchia spp., and Chaetoceros spp.), the average cell size of the cells that formed each chain as well as the length of each chain were measured to estimate their cell abundance in each sample. Note that in both study sites, phytoplankton organisms were not identified taxonomically, and therefore, all the size-scaling analyses conducted in this study were done at the community level. 


\section{Phytoplankton carbon biomass and biomass turnover rates}

In both sampling regions, picophytoplankton biovolume $(V)$ was converted to carbon biomass $(C)$ using the conversion factors detailed by Huete-Ortega et al.

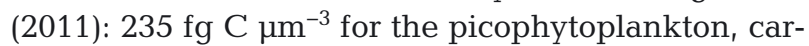
bon content $\left(\mathrm{pg} \mathrm{C}\right.$ cell $\left.^{-1}\right)=0.433 \times V^{0.863}$ for small nanophytoplankton (Verity et al. 1992), and carbon content $\left(\mathrm{pg} \mathrm{C}\right.$ cell $\left.^{-1}\right)=0.109 \times \mathrm{V}^{0.991}$ for large nanoand micro-phytoplankton (Montagnes \& Berges 1994). Subsequently, phytoplankton carbon biomass (PhytoC) was estimated by multiplying cell abundance by cellular carbon biomass. The resulting values were summed to obtain the Phyto-C for pico-, small nano-, large nano-, and micro-phytoplankton. Biomass turnover rates (analogous to intrinsic growth rates) for size-fractionated phytoplankton were calculated by dividing production (carbon fixation rates) by carbon biomass (Kirchman 2002).

\section{Scaling relationship between cell size, total abundance, and carbon fixation rate}

The individual scaling relationships between phytoplankton cell size, total abundance, and carbon fixation rates in both sampling sites were determined as detailed elsewhere (Huete-Ortega et al. 2012). Briefly, to determine the scaling relationship between abundance and cell size for each sample, size classes were established on an octave $\left(\log _{2}\right)$ scale of biovolume, and total cell abundance was calculated for each size class by summing the abundance of all cells within it. Afterward, the $\log _{10}$ of total abundance was plotted against the $\log _{10}$ of the lower limit of the corresponding octave size class (nominal size), obtaining an individual linear relationship. In the open-ocean ecosystem samples, the maximum number of size classes found across all the size-abundance spectra was 24, ranging from 0.5 to $80 \mu \mathrm{m}$ in ESD, whereas in the coastal site, the maximum number of size classes found was 22 , ranging from 0.6 to $63 \mu \mathrm{m}$ in ESD. To obtain the size-scaling of photosynthetic carbon fixation rate, total cell abundance was calculated for those size classes for which the size-fractionated carbon fixation rate had been previously obtained $(0.2$, $0.8,2,3,5,10,20$, and $>40 \mu \mathrm{m}$ ESD). The sizefractionated carbon fixation rate measured on each size class was divided by the total cell abundance in that size class, obtaining the cell-specific carbon fixation rate for each size class. Subsequently, the $\log _{10}$ of the cell-specific carbon fixation rate was plotted against the $\log _{10}$ of the corresponding abundanceweighed mean cell size in each size class to obtain an individual linear relationship. To get a macroecological picture of the size-scaling of metabolism and abundance of the phytoplankton community in the open-ocean and coastal ecosystems in this study, all the individual size-scaling relationships for cellspecific carbon fixation rate and total abundance were pooled together in the same plot. Subsequently, considering the methodological error presented by the variables, the regression slope and intercept of the linear relationship obtained were calculated using a Model II regression analysis as described by Huete-Ortega et al. (2010). As a result, 2 size-scaling relationships were obtained for each sampling site: one for the phytoplankton cell-specific carbon fixation rate and another for phytoplankton total abundance, hereafter referred to as size-cell-specific carbon fixation rate macrospectrum and size-abundance macrospectrum, respectively. When a comparison between slope values was necessary, a Student's $t$-test following the Clarke method was used (Clarke 1980).

\section{RESULTS AND DISCUSSION}

\section{General oceanographic conditions}

The sampling sites selected for this study are representative of 2 markedly contrasting marine ecosystems in terms of their hydrographic features and primary production (Table 1), as described by previous reports (Marañón et al. 2001, Cermeño et al. 2005,

Table 1. Averaged $( \pm 1 \mathrm{SD})$ hydrographic characteristics for the period of sampling of the open-ocean and coastal ecosystems. Temperature, primary production and chlorophyll a concentration values are from the surface. Brunt-Väisäla frequency is averaged over the euphotic layer depth

\begin{tabular}{|lccccc|}
\hline & Temp. $\left({ }^{\circ} \mathrm{C}\right)$ & $\begin{array}{c}\text { Brunt-Väisäla } \\
\text { frequency }\left(\mathrm{s}^{-2}\right)\end{array}$ & $\begin{array}{c}\text { Total primary prod. } \\
\left(\mathrm{mg} \mathrm{C} \mathrm{m}^{-3} \mathrm{~h}^{-1}\right)\end{array}$ & $\begin{array}{c}\text { Total chl } a \text { conc. } \\
\left(\mathrm{mg} \mathrm{m}^{-3}\right)\end{array}$ & $\begin{array}{c}\text { Chl } a>20 \mu \mathrm{m} \\
(\%)\end{array}$ \\
\hline Open ocean & $25.3 \pm 1.9$ & $0.0002 \pm 0.0001$ & $0.22 \pm 0.19$ & $0.16 \pm 0.06$ & $25 \pm 11$ \\
Coastal & $15.1 \pm 1.1$ & $0.017 \pm 0.013$ & $19.35 \pm 19.49$ & $1.90 \pm 1.37$ & $47 \pm 27$ \\
\hline
\end{tabular}


2006). In the open-ocean ecosystem, we find warm surface temperatures, strong stratification (evidenced by the low values of the Brunt-Väisäla frequency), and low nutrient (oligotrophic) concentrations in the upper mixed layer that result in low phytoplankton primary production and chl a concentrations dominated by the smallest phytoplankton, the picophytoplankton. Hydrodynamically, this system can be regarded as being close to steady-state: nutrients enter the euphotic zone continuously at a slow rate and are continuously consumed by the phytoplankton, so that nutrient concentration never increases markedly (Eppley et al. 1973, Lewis et al. 1986). Conversely, the coastal ecosystem exhibits low sea surface temperatures and enhanced vertical mixing both inside and outside Ría de Vigo (evidenced by the high values of the Brunt-Väisäla frequency), representing a highly dynamic and productive ecosystem far from steady-state, where nutrients enter the euphotic zone episodically as a result of the coastal upwelling (Álvarez-Salgado et al. 1996, Moncoiffé et al. 2000). In this ecosystem, biomass and primary production are dominated by large-size phytoplankton - the microphytoplankton. Therefore, these differences in water column stability and nutrient supply dynamics justified the site selection, to analyze the variability of broad-scale macroecological patterns in the relationship between phytoplankton cell size, abundance, biomass, and metabolism.

\section{Size-scaling of phytoplankton cell-specific metabolism}

The slopes (1.17 for open ocean; 0.90 for coastal system) of the size-cell-specific carbon fixation macrospectra were significantly different from 0.75 ( $t$-test, $\mathrm{p}<0.001$ and $\mathrm{p}=0.002$, respectively) but statistically indistinguishable from 1 , indicating an isometric relationship between phytoplankton cell-specific metabolic rate and cell size in both ecosystems (Fig. 2a). Individual log-log size-scaling relationships determined in the coastal region exhibited a high variability, with slope values in the range of 0.78 to 1 (Table A1 in the Appendix) and, in most cases, not significantly different from 1 (details of the individual relationships from the open ocean are given by Huete-Ortega et al. 2012). This isometric sizescaling of cell-specific carbon fixation rate confirms previous reports about the deviation from the $3 / 4$-power rule of the metabolism of heterotrophic (Johnson et al. 2009, DeLong et al. 2010) and photoautotrophic unicellular organisms; both in culture experiments
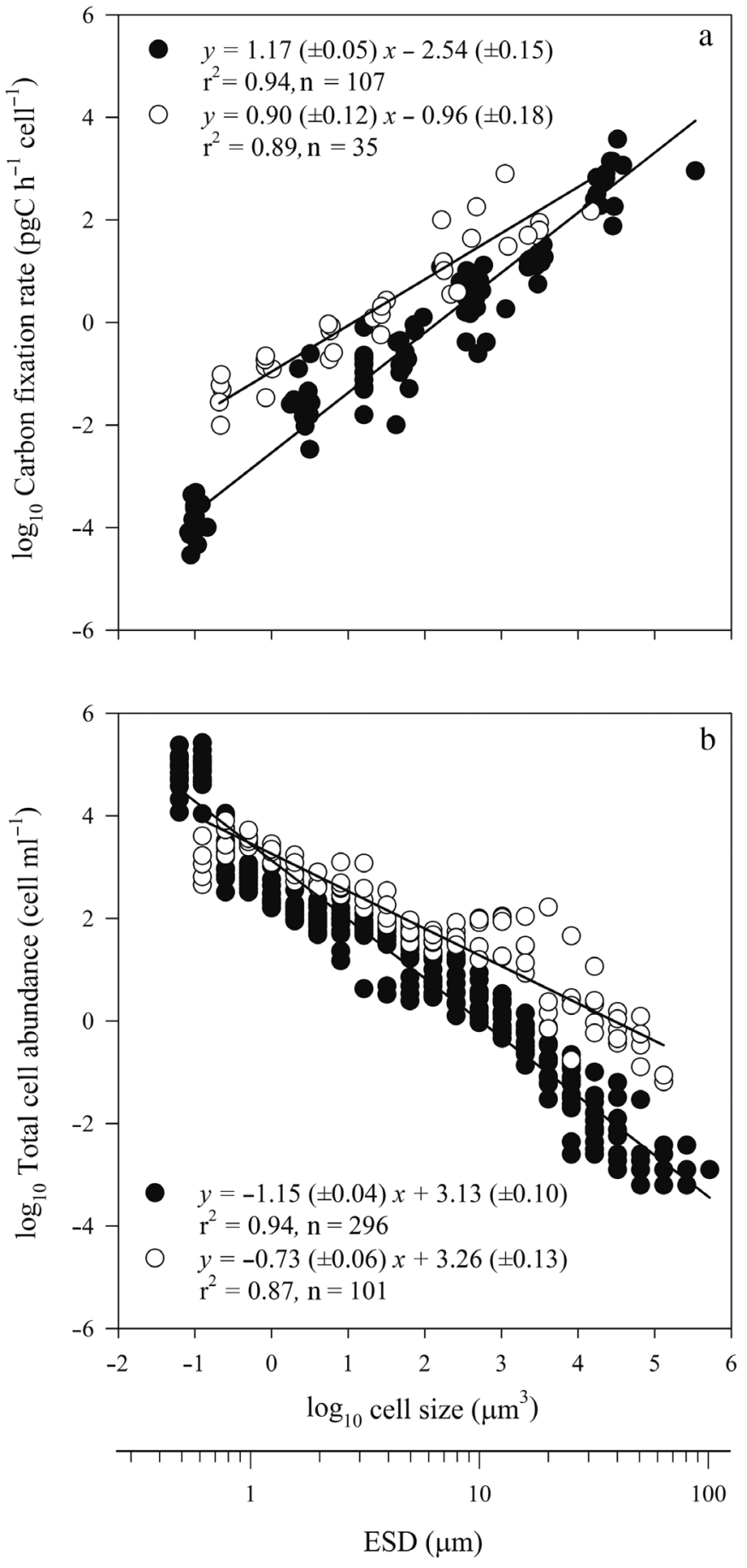

Fig. 2. Pooled individual log-log size-scaling relationships (macrospectra) of (a) cell-specific carbon fixation rate and (b) total abundance for surface phytoplankton collected in the open-ocean ( ) and coastal (O) ecosystems, respectively. Statistical parameters of the Model II regression lines estimated over the macrospectra for the open-ocean and coastal systems are given, with $\mathrm{n}$ being the number of data points and $r^{2}$ the determination coefficient. Parentheses: bootstrapped $95 \%$ CIs for the intercepts and slopes. Phytoplankton size is represented as $\log _{10}$ cell volume and equivalent spherical diameter (ESD) 
(López-Sandoval et al. 2013, 2014, Marañón et al. 2013) and natural communities (Marañón et al. 2007, Huete-Ortega et al. 2012). Interestingly, despite the fact that the primary production of both systems differs by $>80$-fold, the same pattern applies to them, that is, mass (or volume)-specific carbon fixation rates are roughly independent of cell size for phytoplankton cells spanning $>8$ orders of magnitude in cell volume. This result agrees with the observation in laboratory cultures that large and small species sustain similar growth and carbon specific production rates (Marañón et al. 2013, López-Sandoval et al. 2014). The former study also found that intermediate species were able to grow faster than their smaller and larger counterparts, which corresponds to the existence of curvature in metabolic scaling (Kolokotrones et al. 2010, López-Sandoval et al. 2014). Detection of this curvature in natural assemblages, how-
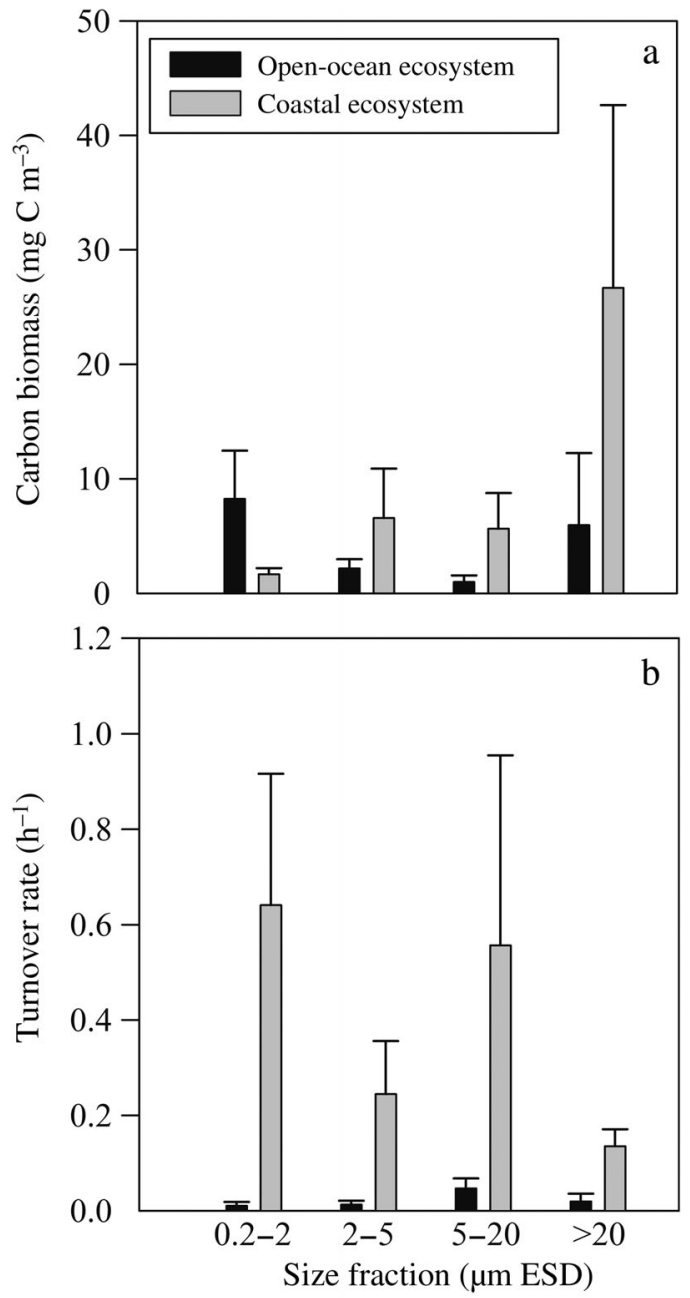

Fig. 3. Averaged size-fractionated (a) carbon biomass and (b) biomass turnover rate for the open-ocean and coastal ecosystems. Error bars $=1 \mathrm{SD}$ ever, is difficult because aggregation of cells from multiple species into a few discrete size classes results in loss of resolution in the determination of size-metabolism scaling relationships.

The nearly isometric size-scaling of phytoplankton cell-specific carbon fixation rates may be explained by a combination of several geometrical, morphological, and physiological traits along the size spectrum (Marañón et al. 2007, Huete-Ortega et al. 2012). Due to their small surface to volume ratio and their thicker diffusive boundary layer, larger phytoplankton cells are at a disadvantage for the uptake of nutrients, especially when nutrients are in short supply (Chisholm 1992, Raven 1998, Armstrong 2008). However, several traits of large cells may help them to overcome, at least partially, this size-related constraint. For instance, large phytoplankton have a large nutrient storage capacity (Stolte \& Riegman 1995), which is particularly beneficial in environments subjected to intermittent nutrient supply. Increases in the carbon to nitrogen and carbon to phosphorus ratio, typically observed in larger cells, represents a way to increase in cell size (and thus obtain refuge from predation) without increasing nutrient requirements to the same extent (Thingstad et al. 2005). Finally, larger cells growing in nutrient-enriched environments are able to sustain higher nitrogen-specific maximum nitrogen uptake rates than smaller cells, which results in a greater ability to acquire nutrients when nutrients are available in large amounts (Marañón et al. 2013).

\section{Size-scaling of phytoplankton abundance and biomass}

The slope of the size-abundance macrospectrum constructed for the open-ocean ecosystem was -1.15 , while we found a lower value, -0.73 , in the coastal one (Fig. 2b), wherein the slope values for the individual $\log -\log$ size-scaling relationships ranged between -0.79 and -0.67 (Table A1; details of individual relationships from the open ocean are given by Huete-Ortega et al. 2012). This pattern is consistent with previous inter-ecosystem comparisons of the relationship between phytoplankton abundance and cell size (Cavender-Bares et al. 2001, Cermeño \& Figueiras 2008, Huete-Ortega et al. 2010). Phytoplankton carbon biomass (Phyto-C) varied from 0.9 to $8.2 \mathrm{mg} \mathrm{C} \mathrm{m}^{-3}$ and from 1.7 to $26.7 \mathrm{mg} \mathrm{C} \mathrm{m}^{-3}$ in the open-ocean and coastal ecosystems, respectively (Fig. 3a). Comparing both regions, carbon biomass values were higher in the coastal ecosystem for all phytoplankton size classes except the picophytoplankton, 
for which Phyto-C was 7-fold higher in the open ocean. We obtained small differences in carbon biomass between both ecosystems for the small and large nanophytoplankton. While Phyto-C was dominated by picophytoplankton in the open-ocean ecosystem, in the coastal ecosystem we observed a change in biomass dominance toward microphytoplankton and an increased contribution of this large-sized class to total chl a from $25 \%$ to $47 \%$ (Table 1). This change in the biomass size structure from open-ocean to coastal waters was in concert with an $~ 11$-fold increase in chl a concentration and an increase in the total standing stock of biomass (Table 1, Fig. 3a), as reported in previous works (Chisholm 1992, Marañón et al. 2012). This pattern seemed to be also reflected in the slight departure from the linearity of total cell abundance between $10^{3}$ and $10^{5} \mu^{3}$ (Fig. 2b, white dots), which implied an increased abundance of cells within some specific large-sized classes.

\section{Size-scaling of phytoplankton energy use}

Following Damuth's energy equivalence rule (EER; Damuth 1981), previous works have reported that the flow of energy associated with the photosynthetic activity of phytoplankton along the size spectrum can be assessed by multiplying, for each size class, the cell-specific carbon fixation rate by the total cell abundance, to obtain a scaling relationship between total carbon fixation per unit volume and cell size (Marañón et al. 2007, Huete-Ortega et al. 2012). In the present study, we found contrasting macroecological patterns in the size-scaling of energy use in the 2 ecosystems. In the open-ocean ecosystem, we did not find statistically significant linear relationships for this variable, either individually (see HueteOrtega et al. 2012) or by plotting all the data together in a single size-carbon fixation rate macrospectrum (Fig. 4, black dots). This result indicates that the total use of energy due to phytoplankton photosynthesis is independent of cell size in the open ocean. Conversely, we obtained a statistically significant linear relationship with a slope of 0.40 for the size macrospectrum of total carbon fixation per unit volume in the coastal ecosystem, meaning that the flow of phytoplankton photosynthetic energy increases with cell size in this ecosystem (Fig. 4, white dots). These observations argue against the idea of a universal invariance of organisms' total energy use and agree with recent reports of deviations toward an increase in the use of energy by large organisms (Hayward et al. 2009, DeLong 2011, Isaac et al. 2011).

\section{Mechanisms driving differences in natural phytoplankton community size structure between the two ecosystems}

A combination of both bottom-up and top-down factors would determine the different size abundance distribution patterns of phytoplankton in coastal and open-ocean ecosystems. The main difference between the studied sites lies in their water-column dynamics, which largely determines the nutrient supply. In this sense, we argue that differences in the magnitude and variability of this nutrient supply, and their interactions with the physiological constraints of phytoplankton, contribute to explain the different way in which the size-scaling of metabolic rate is functionally linked to the size-scaling of abundance in coastal and open-ocean systems. From this functional linkage, the size abundance distribution of phytoplankton communities arises, and the size-differential effect of the grazing pressure on phytoplankton helps to shape their final size structure.

We observed high variability in phytoplankton biomass turnover rates amongst size classes in the open ocean (0.01 to $0.04 \mathrm{~h}^{-1}$ ) and coastal (0.14 to $0.64 \mathrm{~h}^{1}$ ) ecosystems (Fig. 3b), although there was not a clear pattern of dominance amongst them for both systems. Phytoplankton turnover rates coincided with previ-

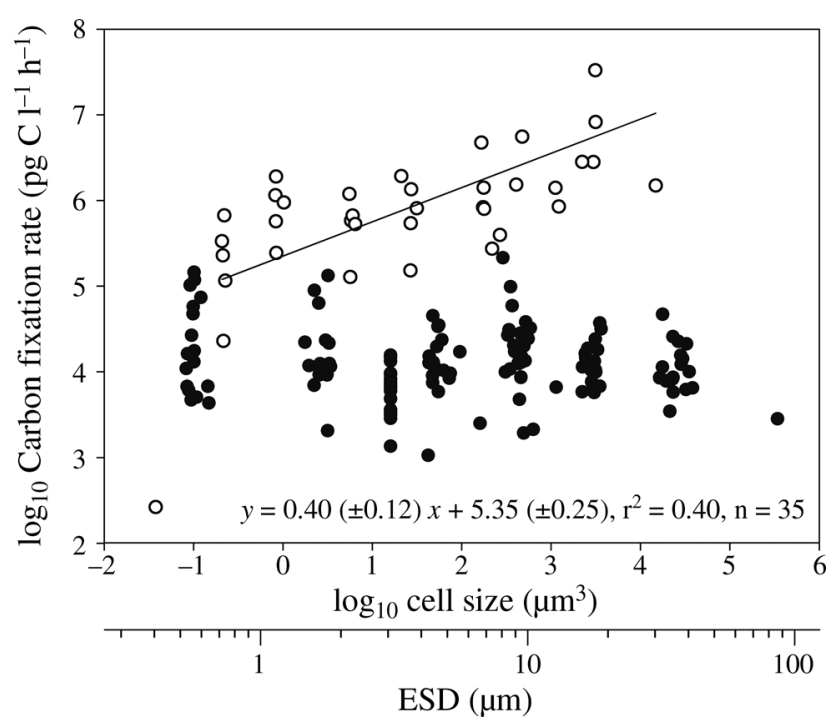

Fig. 4. Pooled individual log-log relationships (macrospectrum) between total carbon fixation rate per unit volume and cell size for surface phytoplankton collected in the openocean (๑) and coastal (O) ecosystems. Model II regression lines and statistical parameters as in Fig. 1. Phytoplankton size is represented as $\log _{10}$ cell volume and equivalent spherical diameter (ESD). No details are given for the open-ocean system, as no statistically significant regression relationship was found 
ous values reported for the same oceanic regions (Goericke \& Welschmeyer 1998, Lessard \& Murrel 1998, Cermeño et al. 2005, Marañón 2005) and were markedly higher in coastal waters than in the oligotrophic open ocean (10-fold difference on average), consistent with the increasing trend described by a bio-optical model in Behrenfeld et al. (2005). On average, phytoplankton growth rate in the open ocean was $0.13 \mathrm{~d}^{-1}-$ much lower than the maximum theoretical value $\left(\sim 1.5 \mathrm{~d}^{-1}\right)$ estimated by Eppley (1972) for phytoplankton growing in tropical oceans. Conversely, in the coastal ecosystem, we estimated a phytoplankton growth rate of $2.2 \mathrm{~d}^{-1}$, higher than the value of $\sim 1 \mathrm{~d}^{-1}$ inferred from growth-temperature relationships. We thus conclude that, in contrast to more productive and highly dynamic marine ecosystems, a physiological limitation of phytoplankton growth throughout the size spectrum exists in the open ocean. This conclusion is in agreement with ample experimental evidence that demonstrates that mainly nitrogen limitation (and sometimes nitrogen and phosphorus co-limitation) results in physiological impairment of phytoplankton growth in open-ocean, oligotrophic regions (Mills et al. 2004, Marañón 2005, Moore et al. 2008, 2013).

The superlinear size-scaling of phytoplankton abundance found for the open-ocean ecosystem was suggested to be mainly driven by the interaction of the nutrient supply dynamics typical of nutrientimpoverished, near steady-state marine environments, with the nutrient limitation and the size-specific physiological properties of the phytoplankton inhabiting this kind of ecosystem (Huete-Ortega et al. 2012). This interaction would manifest in the reciprocity found between the size-scalings of phytoplankton metabolic rate and abundance (i.e. EER; Enquist et al. 1998), in which the higher grazing pressure on the small phytoplankton would be compensated by losses in the large phytoplankton associated with higher sedimentation rates. However, such reciprocity is not observed in the present study for the more dynamic and nutrient-enriched marine ecosystem (see Fig. 2 and Fig. A1), suggesting that additional features might be playing a role in determining the size-abundance distribution of coastal phytoplankton.

Coastal ecosystems are characterized by highly dynamic regimes of light and nutrient concentrations (Álvarez-Salgado et al. 1996, Gargett 1997). Many studies have reported a positive relationship between the temporal variability of resource supply, water column hydrodynamics and the selection for large phytoplankton species (Grover 1991, Edwards et al.
2011, Kerimoglu et al. 2012). Large phytoplankton have high nutrient-specific maximum nutrient uptake rates and a large nutrient-storage capacity (Stolte \& Riegman 1995, Marañón et al. 2013) in comparison to smaller cells. These physiological features allow them to take advantage of intermittent nutrient pulses and outcompete small-sized species. Additionally, large species have a greater capacity to survive in fluctuating-light environments due to the low susceptibility of their photosynthetic apparatus to damage by high light intensities (Key et al. 2010). Therefore, the same biophysical and physiological features described above to explain the isometric size-scaling of metabolic rate would enable larger species to physiologically outcompete small ones during conditions of intermittent nutrient supply. In this study, these mechanisms increased large phytoplankton abundance and biomass in the nutrient-rich conditions of the coastal ecosystem, and determined the flow of photosynthetic energy along the community size spectrum.

In addition to the interaction between phytoplankton physiology and resource supply dynamics, topdown factors would also control the size structure of phytoplankton communities. Traditionally, it has been widely accepted that grazing pressure tends to favor the dominance of large cells in settings of enhanced phytoplankton growth (Kiørboe 1993, Macías et al. 2010, Poulin \& Franks 2010, Ward et al. 2012). However, several observational studies have recently suggested that the size-dependence of phytoplankton mortality due to grazing may be lower than generally assumed. For instance, Gutiérrez-Rodríguez et al. (2011) found that phytoplankton groups with very different mean cell sizes suffered similar rates of grazing. Similarly, Chang et al. (2013) did not find any indication of a decrease in grazing pressure with increasing phytoplankton cell size. Finally, grazing losses due to microzooplankton, which are the main consumers of phytoplankton production, are similar in ecosystems with markedly different phytoplankton size structures (Calbet \& Landry 2004, Schmoker et al. 2013). Despite this open debate about the effect of grazing pressure along the phytoplankton size spectrum, it is clear that top-down controls affect phytoplankton size abundance distribution in both coastal and open-ocean ecosystems. Therefore, we hypothesize here that this ecological pressure would contribute to shape the final size structure of phytoplankton communities, in turn determined by the interaction between the size-scaling of key physiological properties of phytoplankton and the dynamics of nutrient supply. 
Acknowledgements. We thank L. Díaz, P. Chouciño and M. P. Lorenzo for technical support and the officers and crew of R/V 'Hespérides' and R/V 'Mytilus', as well as the staff of the Marine Technology Unit (UTM), for their help during the work at sea. We also appreciate J. P. DeLong and an anonymous reviewer for their helpful comments. D.C.L.S. and T.R.R were supported by postgraduate fellowships from the Spanish Ministry of Education, the Mexican Council of Science and Technology (CONACyt) and the Xunta de Galicia (Spain). M.H.O. was supported by the postdoctoral fellowship Fundación Juana de Vega and P.C. by the postdoctoral research program Ramon y Cajal. We acknowledge the funding received from the Spanish Ministry of Science and Innovation through projects 'Trichodesmium and nitrogen fixation in the Atlantic Ocean' (CTM2004-05174-C02), 'Macroecological patterns in marine phytoplankton' (CTM200803699), and 'MALASPINA 2010' (CSD2008-00077).

\section{LITERATURE CITED}

Álvarez-Salgado XA, Rosón G, Pérez FF, Figueiras FG, Pazos Y (1996) Nitrogen cycling in an estuarine upwelling system, the Ría de Arousa (NW Spain). I. Short-time-scale patterns of hydrodynamic and biogeochemical circulation. Mar Ecol Prog Ser 135:259-273

Armstrong RA (2008) Nutrient uptake rate as a function of cell size and surface transporter density: a Michaelis-like approximation to the model of Pasciak and Gavis. DeepSea Res I 55:1311-1317

Behrenfeld MJ, Boss E, Siegel DA, Shea DM (2005) Carbonbased ocean productivity and phytoplankton physiology from space. Global Biogeochem Cycles 19:GB1006, doi: 10.1029/2004GB002299

Calbet A, Landry MR (2004) Phytoplankton growth, microzooplankton grazing, and carbon cycling in marine systems. Limnol Oceanogr 49:51-57

Cavender-Bares K, Rinaldo A, Chisholm SW (2001) Microbial size spectra from natural and nutrient enriched ecosystems. Limnol Oceanogr 46:778-789

Cermeño P, Figueiras FG (2008) Species richness and cellsize distribution: size structure of phytoplankton communities. Mar Ecol Prog Ser 357:79-85

Cermeño P, Marañón E, Rodríguez J, Fernández E (2005) Large-sized phytoplankton sustain higher carbon-specific photosynthesis than smaller cells in a coastal eutrophic ecosystem. Mar Ecol Prog Ser 297:51-60

> Cermeño P, Marañón E, Pérez V, Serret P, Fernández E, Castro CG (2006) Phytoplankton size structure and primary production in a highly dynamic coastal ecosystem (Ría de Vigo, NW-Spain): seasonal and short-time scale variability. Estuar Coast Shelf Sci 67:251-266

Chang FH, Marquis EC, Chang CW, Gong GC, Hsieh CH (2013) Scaling of growth rate and mortality with size and its consequence on size spectra of natural microphytoplankton assemblages in the East China Sea. Biogeosciences 10:5267-5280

Chisholm SW (1992) Phytoplankton size. In: Falkowski PG, Woodhead AD (eds) Primary productivity and biogeochemical cycles in the sea. Plenum Press, New York, NY, p 213-236

Clarke MRB (1980) The reduced major axis of a bivariate sample. Biometrika 67:441-446

> Damuth J (1981) Population density and body size in mammals. Nature 290:699-700

> DeLong JP (2011) Energetic inequivalence in eusocial insect colonies. Biol Lett 7:611-614
DeLong JP, Okie JG, Moses ME, Sibly RM, Brown JH (2010) Shifts in metabolic scaling, production, and efficiency across major evolutionary transitions of life. Proc Natl Acad Sci USA 107:12941-12945

Edwards KF, Klausmeier CA, Litchman E (2011) Evidence for a three-way trade-off between nitrogen and phosphorous competitive abilities and cell size in phytoplankton. Ecology 92:2085-2095

> Enquist BJ, Brown JH, West GB (1998) Allometric scaling of plant energetics and population density. Nature 395: 163-165

Eppley RW (1972) Temperature and phytoplankton growth in the sea. Fish Bull 70:1063-1085

Eppley RW, Renger EH, Venrick EL, Mullin MM (1973) A study of plankton dynamics and nutrient cycling in the central gyre of the North Pacific Ocean. Limnol Oceanogr 18:534-551

Falkowski PG, Barber RT, Smetacek V (1998) Biogeochemical controls and feedbacks on ocean primary production. Science 281:200-206

Falkowski PG, Katz ME, Knoll AH, Quigg A, Raven JA, Scholfield O, Taylor FJR (2004) The evolution of modern eukaryotic phytoplankton. Science 305:354-360

Field CB, Behrenfeld MJ, Randerson JT, Falkowski PG (1998) Primary production of the biosphere: integrating terrestrial and oceanic components. Science 281:237-240

Finkel ZV, Vaillancourt CJ, Irwin AJ, Reavie ED, Smol JP (2009) Environmental control of diatom community size structure varies across aquatic ecosystems. Proc R Soc B 276:1627-1634

> Gargett AE (1997) Physics to fish: interactions between physics and biology on a variety of scales. Oceanography 10:128-131

> Goericke R, Welschmeyer NA (1998) Response of Sargasso Sea phytoplankton biomass, growth rates and primary production to seasonally varying physical forcing. J Plankton Res 20:2223-2249

> Grover JP (1991) Resource competition among microalgae in a variable environment: experimental tests of alternative models. Oikos 62:231-243

Gutiérrez-Rodríguez A, Latasa M, Agustí S, Duarte CM (2011) Distribution and contribution of major phytoplankton groups to carbon cycling across contrasting conditions of the subtropical northeast AtlanticOcean. Deep-Sea Res I 58:1115-1129

Hayward A, Khalid M, Kolasa J (2009) Population energy use scales positively with body size in natural aquatic microcosms. Glob Ecol Biogeogr 18:553-562

Huete-Ortega M, Marañón E, Varela M, Bode A (2010) General patterns in the size scaling of phytoplankton abundance in coastal waters during a 10-year time series. J Plankton Res 32:1-14

Huete-Ortega M, Calvo-Díaz A, Mouriño-Carballido B, Graña R, Marañón E (2011) Effect of environmental forcing on the biomass, production and growth rate of sizefractionated phytoplankton in the central Atlantic. J Mar Syst 88:203-213

Huete-Ortega M, Cermeño P, Calvo-Díaz A, Marañón E (2012) Isometric size-scaling of metabolic rate and the size abundance distribution of phytoplankton. Proc R Soc B 279:1815-1823

Irwin A, Finkel ZV, Schofield OME, Falkowski PG (2006) Scaling-up from nutrient physiology to the size-structure of phytoplankton communities. J Plankton Res 28:459-471

> Isaac NJB, Storch D, Carbone C (2011) Taxonomic variation in size-density relationships challenges the notion of energy equivalence. Biol Lett 7:615-618 
Johnson MD, Völker J, Moeller HV, Laws E, Breslauer KJ, Falkowski PG (2009) Universal constant for heat production in protists. Proc Natl Acad Sci USA 106:6696-6699

Kerimoglu O, Straile D, Peeters F (2012) Role of phytoplankton cell size on the competition for nutrients and light in incompletely mixed waters. J Theor Biol 300:330-343

> Key T, McCarthy A, Campbell DA, Six C, Roy S, Finkel ZV (2010) Cell size trade-offs govern light exploitation strategies in marine phytoplankton. Environ Microbiol 12:95-104

Kiørboe T (1993) Turbulence, phytoplankton cell size and the structure of pelagic food webs. Adv Mar Biol 29:1-72

Kirchman DL (2002) Calculating microbial growth rates from data on production and standing stocks. Mar Ecol Prog Ser 233:303-306

> Kleiber M (1947) Body size and metabolic rate. Physiol Rev 27:511-541

> Kolokotrones T, Savage V, Deeds EJ, Fontana W (2010) Curvature in the metabolic scaling. Nature 464:753-756

> Legendre L, Rassoulzadegan F (1996) Food-web mediated export of biogenic carbon in oceans: hydrodynamic control. Mar Ecol Prog Ser 145:179-193

> Lessard EJ, Murrel MC (1998) Microzooplankton herbivory and phytoplankton growth in the northwestern Sargasso Sea. Aquat Microb Ecol 16:173-188

Lewis MR, Hebert D, Harrison WG, Platt T, Oakey NS (1986) Vertical nitrate fluxes in the oligotrophic ocean. Science 234:870-873

> Litchman E, Klausmeier CA (2008) Trait-based community ecology of phytoplankton. Annu Rev Ecol Evol Syst 39: 615-639

Litchman E, Edwards KF, Klausmeier CA, Thomas MK (2012) Phytoplankton niches, traits and eco-evolutionary responses to global environmental change. Mar Ecol Prog Ser 470:235-248

López-Sandoval DC, Rodríguez-Ramos T, Cermeño $\mathrm{P}$, Marañón E (2013) Exudation of organic carbon by marine phytoplankton: dependence on taxon and cell size. Mar Ecol Prog Ser 477:53-60

López-Sandoval DC, Rodríguez-Ramos T, Cermeño P, Sobrino C, Marañón E (2014) Photosynthesis and respiration in marine phytoplankton: relationship with cell size, taxonomic affiliation, and growth phase. J Exp Mar Biol Ecol 457:151-159

López-Urrutia A, San Martin E, Harris RP, Irigoien X (2006) Scaling the metabolic balance of the oceans. Proc Natl Acad Sci USA 103:8739-8744

Lund JWG, Kipling C, Le Cren ED (1958) The inverted microscope method of estimating algal numbers and the statistical basis of estimations by counting. Hydrobiologia 11:143-170

Macías D, Ramirez-Romero E, García CM (2010) Effect of nutrient input frequency on the structure and dynamics of the marine pelagic community: a modeling approach. J Mar Res 68:119-151

> Marañón E (2005) Phytoplankton growth rates in the Atlantic subtropical gyres. Limnol Oceanogr 50:299-310

> Marañón E, Cermeño P, López-Sandoval DC, RodríguezRamos T and others (2013) Unimodal size scaling of phytoplankton growth and the size dependence of nutrient uptake and use. Ecol Lett 16:371-379

- Marañón E, Holligan PM, Barciela R, González N, Mouriño B, Pazó MJ, Varela M (2001) Patterns of phytoplankton size-structure and productivity in contrasting open ocean environments. Mar Ecol Prog Ser 216:43-56

> Marañón E, Cermeño P, Rodríguez J, Zubkov MV, Harris HP (2007) Scaling of phytoplankton photosynthesis and cell size in the ocean. Limnol Oceanogr 52:2190-2198
Marañón E, Cermeño P, Latasa M, Tandonléké RM (2012) Temperature, resources, and phytoplankton size structure in the ocean. Limnol Oceanogr 57:1266-1278

Marquet PA, Quiñones RA, Abades S, Labra F, Tognelli M, Arim M, Rivadeneira M (2005) Scaling and power-laws in ecological systems. J Exp Biol 208:1749-1769

> McGill BJ, Enquist BJ, Weiher E, Westoby M (2006) Rebuilding community ecology from functional traits. Trends Ecol Evol 21:178-185

Mills MM, Ridame C, Davey M, La Roche J, Geider RJ (2004) Iron and phosphorous co-limit nitrogen fixation in the eastern tropical North Atlantic. Nature 429: 292-294

> Moncoiffé G, Álvarez-Salgado XA, Figueiras FG, Savidge G (2000) Seasonal and short-time-scale dynamics of microplankton community production and respiration in an inshore upwelling system. Mar Ecol Prog Ser 196:111-126

Montagnes DJS, Berges JA (1994) Estimating carbon, nitrogen, protein, and chlorophyll a from volume in marine phytoplankton. Limnol Oceanogr 39:1044-1060

Moore CM, Mills MM, Langlois R, Milne A, Achterberg EP, LaRoche J, Geider RJ (2008) Relative influence of nitrogen and phosphorous availability on phytoplankton physiology and productivity in the oligotrophic subtropical North Atlantic Ocean. Limnol Oceanogr 53: 291-305

> Moore CM, Mills MM, Arrigo KR, Berman-Frank I and others (2013) Processes and patterns of oceanic nutrient limitation. Nat Geosci 6:701-710

Peters RH (1983) The ecological implications of body size. Cambridge University Press, Cambridge

Poulin FJ, Franks PJS (2010) Size-structure planktonic ecosystems: constraints, controls and assembly instructions. J Plankton Res 32:1121-1130

Raven JA (1998) The twelfth Tansley Lecture. Small is beautiful: the picophytoplankton. Funct Ecol 12:503-513

Reul A, Rodríguez V, Jiménez-Gómez F, Blanco JM and others (2005) Variability in the spatio-temporal distribution and size-structure of phytoplankton across an upwelling area in the NW-Alboran Sea, (W-Mediterranean). Cont Shelf Res 25:589-608

Schmoker C, Hernández-León S, Calbet A (2013) Microzooplankton grazing in the oceans: impacts, data variability, knowledge gaps and future directions. J Plankton Res 35:691-706

Sheldon RW, Prakash A, Sutcliffe WH (1972) The size distribution of particles in the ocean. Limnol Oceanogr 17: 327-340

Stolte W, Riegman R (1995) Effect of phytoplankton cell size on transient-state nitrate and ammonium uptake kinetics. Microbiology 141:1221-1229

Taguchi S (1976) Relationship between photosynthesis and cell size of marine diatoms. J Phycol 12:185-189

> Thingstad TF, Øvreås L, Egge JK, Løvdal T, Heldal M (2005) Use of non-limiting substrates to increase size; a generic strategy to simultaneously optimize uptake and minimize predation in pelagic osmotrophs? Ecol Lett 8: $675-682$

> Verity PG, Robertson CY, Tronzo CR, Andrews MG, Nelson JR, Sieracki ME (1992) Relationships between cell volume and the carbon and nitrogen content of marine photosynthetic nanoplankton. Limnol Oceanogr 37: 1434-1446

Ward BA, Dutkiewicz S, Jahn O, Follows MJ (2012) A sizestructured food-web model for the global ocean. Limnol Oceanogr 57:1877-1891

Westoby M, Wright IJ (2006) Land-plant ecology on the basis of functional traits. Trends Ecol Evol 21:261-268 
Appendix. Additional data

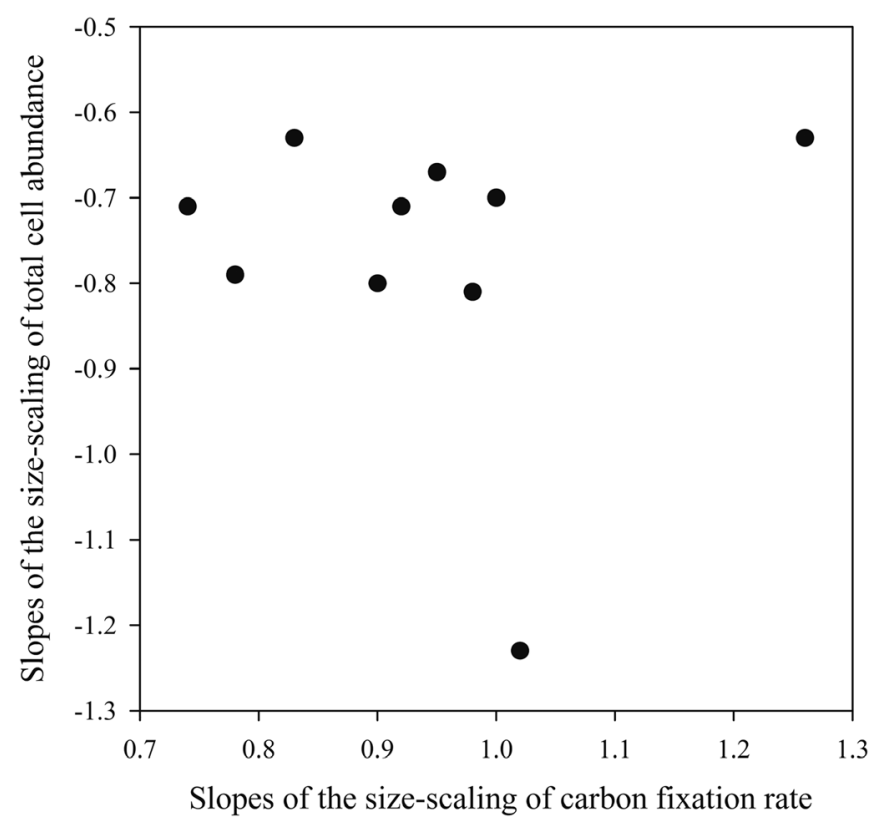

Fig. A1. Relationship between the slopes of the size-scaling of cell-specific carbon fixation rate and total cell abundance obtained for the coastal ecosystem. No significant linear regression was found ( $p$-value $=0.88$ ), indicating the absence of reciprocity between the size-scaling of abundance and metabolic rate

Table A1. Statistical parameters of the log-log scaling relationships between cell size, total cell abundance and cell-specific carbon fixation rate obtained for the coastal ecosystem. Sampling at the stations $42.24^{\circ} \mathrm{N}, 8.79^{\circ} \mathrm{W}$ and $42.16^{\circ} \mathrm{N}, 8.94^{\circ} \mathrm{W}$ are referred as Inside and Outside, respectively. For each type of relationship, $a$ and $c$ are the Model II intercepts, $b$ and $d$ refer to the Model II slopes, $\mathrm{n}$ indicates the number of data points, and $\mathrm{r}^{2}$ is the determination coefficient. $95 \%$ CIs for the intercepts and slopes are in parentheses. $\mathrm{p}$-value refers to the comparison between the size-scaling slope of metabolic rate with the expected value of 3/4, as detailed by Clarke (1980)

\begin{tabular}{|c|c|c|c|c|c|c|c|c|c|}
\hline \multirow[t]{2}{*}{ Date of sampling } & \multicolumn{5}{|c|}{- Size-scaling of cell-specific carbon fixation rate- } & \multicolumn{4}{|c|}{ - Size-scaling of total abundance } \\
\hline & $d$ & C & $\mathrm{r}^{2}$ & $\mathrm{n}$ & $\mathrm{p}$ & $b$ & $a$ & $\mathrm{r}^{2}$ & $\mathrm{n}$ \\
\hline 19 May 2010. Inside & $0.78(0.62,0.90)$ & $-1.21(-1.51,-0.96)$ & 0.97 & 7 & 0.590 & $-0.79(-0.92,-0.64)$ & $3.17(2.85,3.56)$ & 0.84 & 20 \\
\hline 26 May 2010. Inside & $0.95(0.78,1.11)$ & $-1.03(-1.27,-0.70)$ & 0.97 & 7 & 0.007 & $-0.67(-0.77,-0.57)$ & $2.99(2.77,3.25)$ & 0.94 & 21 \\
\hline 2 June 2010. Outside & $0.92(0.66,1.28)$ & $-0.74(-1.46,-0.54)$ & 0.88 & 7 & 0.176 & $-0.71(-0.79,-0.60)$ & $3.20(3.02,3.44)$ & 0.90 & 19 \\
\hline 30 June 2010. Outside & $0.74(0.65,0,87)$ & $-0.76(-0.96,-0.50)$ & 0.98 & 7 & 0.821 & $-0.71(-0.79,-0.60)$ & $3.34(3.21,3.46)$ & 0.97 & 20 \\
\hline 28 July 2010. Inside & $1.00(0.73,1.53)$ & $-0.92(-1.60,-0.61)$ & 0.87 & 7 & 0.076 & $-0.70(-0,84,-0.50)$ & $3.51(3.20,3.93)$ & 0.79 & 21 \\
\hline
\end{tabular}

Editorial responsibility: Graham Savidge, Portaferry, UK
Submitted: November 20, 2013; Accepted: August 19, 2014 Proofs received from author(s): October 26, 2014 